\title{
Biyoloji Öğretmen Adaylarının Evrim Teorisi Hakkındaki Kavram Yanılgıları
}

\author{
Bülent KESKİN ${ }^{1 *}$, Esra ÖZAY KÖSE² \\ ${ }^{1}$ Işıklar Çok Programlı Anadolu Lisesi, Akçaabat, Trabzon; ${ }^{2}$ Atatürk Üniversitesi, Kazım \\ Karabekir Eğitim Fakültesi, Erzurum
}

Makale Gönderme Tarihi: 20.03.2017

Makale Kabul Tarihi: 25.10.2017

Özet - Tüm biyolojik alanlar için merkezi ve birleştirici bir temel teşkil evrim teorisi disiplinler arası bir konudur ve biyolojinin bazı temel kavramlarını anlamada önemli bir rol oynar. Etkili bir şekilde evrim teorisini öğretmek biyoloji öğretmenlerinin sorumluluğunda olduğundan, bu çalışmada biyoloji öğretmen adaylarının evrim teorisi hakkında kavram yanılgılarını tespit etmek amaçlanmıştır. Bu amaçla, çalışma 117 biyoloji öğretmen adayı ile yürütülmüştür. Evrim teorisinin ne olduğu hakkında doğru-yanlış sorulardan oluşan iki aşamalı bir kavram yanılgısı teşhis testi kullanılmıştır. Testten elde edilen nitel ve nicel verilere dayanarak, öğretmenlerin bu konuda bir hayli kavram yanılgısı taşıdıkları tespit edilmiştir. Çalışmaya katılan biyoloji öğretmen adaylarının çoğunluğunun temel evrim teorisinin süreci hakkında yanlış anlamalarının yanı sıra temel evrim kavramları hakkında da bir çok kavram yanılgılarına sahip olmaları dikkat çekicidir. $\mathrm{Bu}$ yanılgıların olası nedenlerini ortadan kaldırmak için önerilerde bulunulmuştur.

Anahtar kelimeler: kavram yanılgıları, biyoloji öğretmen adayları, evrim teorisi, biyoloji eğitimi.

\section{Özet}

Giriş: Biyolojik alanların hepsini birleştirici bir temel oluşturan ve merkezi olarak değerlendirilebilecek olan evrim teorisi, disiplinler arası bir konudur ve biyoloji dersinin temeli olan bazı kavramların anlaşılmasında önemli bir rol oynamaktadır.

Kavram öğretimi, öğrenme süreçlerinde üzerinde sıkça durulması gereken konuların başında yer almaktadır. Bir konu alanına ilişkin kavramların bilinmesi ile bu kavramlar arasındaki ilişkiler yeni öğrenilecek ya da öğretilecek konulara temel oluşturmaktadır. Dolayısıyla, bir kavramın yanlış ya da eksik öğrenilmesi, bundan sonraki ilişsileri de tetikleyeceğinden, sarmal biçimde kavramsal eksikliklere ya da yanılgılara yol açacak sonuçlar ortaya çıkartacaktır (Atasayar, 2008).

Öğrencilerin zihninde oluşan yanlış kavramlar, yeni kavramlarla sağlıklı bağlantılar kurulmasını engelleyerek anlamlı öğrenmenin gerçekleşmesini önemli ölçüde

\footnotetext{
* İletişim: Bülent KESKİN, Dr., Işıklar Çok Programlı Anadolu Lisesi, Akçaabat, Trabzon, TÜRKIYYE.

E-posta: kesbul@yahoo.com

Not: Bu makale ikinci yazarın danışmalığında tamamlanmış birinci yazarın doktora tezinden üretilmiştir.
} 
engellemektedir. Bilginin doğru ve kalıcı olarak öğretilmesinde, var olan kavram yanılgılarının giderilmesi ve yeni kavram yanılgılarının oluşmasının önlenmesi açısından, kavram yanılgılarının önceden bilinmesi büyük önem taşımaktadır (Atılboz, 2004).

Araştırmacılar, öğretmen ve öğrencilerin evrim teorisini anlamadaki güçlüklerini onların sahip olduğu yanılgılara ve daha önceki sahip olduğu bilgilere bağlamaktadırlar (Gregory, 2009; Meir, Perry, Herron ve Kingsolver, 2007). İnsanlar bir şeyi anlamadıklarında genellikle daha önceki bilgileri ve deneyimleri ile alakalı sebepler yaratmak eğilimindedirler (Moore, 2002). Bu ise kişilerde evrim teorisinin boşluklarını, teoriyi tam anlamasını engelleyen hatalı bilgilerle doldurmasına sebep olmaktadır. O halde insanımızın bilimi anlamaktan uzaklaşmasını ve aynı zamanda da geleceğin araştırmacıları olacak kişilerin olumsuz etkilenmesine yol açmaması için yanlış anlamaların oluşmasını engellemek gerekmektedir. $\mathrm{Bu}$ çalışma ile evrim konusunda öğrencilerdeki kavram yanılgılarının tespit edilmesi bu yanılgıların giderilmesi ve öğrencilerin bilimsel teoriyi ve evrimi daha iyi anlamalarına yol açacaktır.

$\mathrm{Bu}$ araştırmanın temel amacı evrim teorisinin derslerde etkili bir şekilde öğretilmesinde görev doğal olarak biyoloji öğretmenlerine düştüğünden, biyoloji öğretmen adaylarının evrim teorisinin ne olduğuna dair kavram yanılgılarını tespit etmektir.

Metod: Biyoloji öğretmen adaylarının kavram yanılgılarının tespit edildiği araştırma nitel ve nicel yaklaşımları içeren karma araştırma desenlerinden gömülü desenin kullanıldığı bir araştırmadır. Gömülü karma desen araştırmalarında da nitel ve nicel veriler eş zamanlı olarak toplanmaktadır, ancak bir veri biçimi diğeri için destekleyici rol oynamaktadır (Creswell, 2008).

Evrim teorisinin ne olduğuna dair kavram yanılgılarının tespiti için araştırma örneklemini Atatürk Üniversitesi Kazım Karabekir Eğitim Fakültesi Ortaöğretim Fen ve Matematik Alanları Eğitimi Bölümü Biyoloji Eğitimimi Anabilim Dalı'nda öğrenim gören 2.,3.,4. ve 5. sınıf 117 biyoloji öğretmen adayı oluşturmuştur.

$\mathrm{Bu}$ çalışmada kullanılan ölçüm aracı araştırmacılar tarafından konuyla ilgili literatürlerde yer alan kavram yanılgıları göz önünde bulundurularak (Fahrenwald, 1999; Gregory, 2009; Köse, 2010; Pazza, Penteado ve Kavako, 2010; Rutledge ve Warden, 1999; Understanding Evolution, 2013; Varela, 2009; Yates, 2011) hazırlanmıştır. Kavram yanılgısı tespit testi 14 sorudan oluşmakta olup doğru-yanlış tipi iki aşamalı şeklinde düzenlenmiştir (Tablo.1). İki aşamalı sorularda, ilk kademede öğrencilerin verdikleri cevabın nedenleri, ikinci kademede açık uçlu cevaplar şeklinde istenmektedir. Testin ikinci aşaması, öğrencilerin 
muhakeme yeteneğini daha iyi ölçebilmek ve daha önce belirlenen yanılgılardan farklı alternatif kavramaların olup olmadığını tespit edebilmek amacıyla açık uçlu bir yapıda düzenlenebilmektedir (Mann ve Treagust, 1998; Voska ve Heikkinen, 2000; Akt. Karataş, Köse ve Coştu, 2003).

Biyoloji öğretmen adaylarının evrim teorisinin ne olduğuna dair kavram yanılgılarının tespitinde test maddelerinin doğru-yanlış kısımları için frekans, yüzde dağılımları kullanılmış olup cevap verme nedenlerinin yazıldığ 1 kısım için nitel veri analiz tekniklerinden betimsel analiz kullanılmıştır.

Bulgular: 14 sorudan 2 tanesinde biyoloji öğretmen adaylarının yaklaşık \%80’i yanlış cevap seçeneğini işaretlemişlerdir (5. ve 9. sorular). 14 sorudan 3 tanesinde ise yaklaş1k \% 70'i yanlış cevap seçeneğini işaretlemişlerdir (3., 7. ve 8. sorular). 14 sorudan 1 tanesinde ise yaklaşık \% 50'si yanlış cevap seçeneğini işaretlemişlerdir (1. soru). Yani 6 soruya biyoloji öğretmen adaylarının yarısından fazlası yanlış cevap vermişlerdir. Kalan 8 soruya ise biyoloji öğretmen adayları \%50'nin altında yanlış cevap seçeneğini işaretlemişlerdir. 14 sorudan 1 soruya ise biyoloji öğretmen adaylarının yaklaşık \%81'i doğru cevap vermişlerdir (10. soru).

Evrim teorisinin ne olduğuna dair kavram yanılgısı tespit testine verilen doğru-yanlış cevapların gerekçeleri ise teker teker okunmuş ve kavram yanılgılı ifadeler kategorileştirilmiştir.

Tartışma ve sonuç: Elde edilen sonuçlara göre kavram yanılgıları tespit testinde biyoloji öğretmen adaylarının çok fazla yanlış cevap seçeneğini işaretledikleri ve cevap gerekçelerinden ise birçok kavram yanılgılarına sahip oldukları gözlenmiştir.

Öğrencilerin büyük bir kısmının biyolojik evrimin dünyanın nasıl oluştuğunu açıklayan bir teori olduğu, evrim teorisini tamamen şansa bağlı gerçekleştiği, basitten karmaşığa doğru bir evrim olduğu, canlılarda meydana gelen değişimlerin çok eskiden beri olduğunu bu sebepten bunların gözlemlenemeyeceği, evrim teorisini destekleyen delillerin var olmadı̆̆ türler arası geçiş fosillerinin bulunmadığını, evrim teorisinin deliller ile desteklenmediği veya deliller ile çürütüldüğü, evrim teorisini kabul etmenin dinsizlik olduğu, bireylerin bazında evrim geçirdiği, türlerin ortak bir ataya değil her türün kendi atasına sahip olduğu kavram yanılgılarına sahip oldukları görülmüştür.

Temel evrim teorisi ve temel kavramlar ile ilgili literatürdeki çalışmalara bakıldığında araştırma sonuçlarını destekleyen çalışmalar görülmektedir (Asghar, Wiles ve Alters, 2007; BouJaoude ve diğerleri, 2011; Deniz, Donelly, ve Y1lmaz, 2008; Fahrenwald, 1999; Graf ve Soran, 2011; Kim ve Nehm, 2010; Pazza, Penteado ve Kavako, 2010; Smith, 2010; van Dijk ve Reydon, 2010). 
Evrimsel süreci açıklayan kavramlara yönelik kavram yanılgılarının olduğu dikkati çekmektedir (Shtulman, 2006). Derslerde öğrencilere bilimsel dili kullanmaları için daha fazla olanak sağlanması durumunda, öğrencilerin bu kavramların bilimsel içeriklerine yoğunlaşacakları ve günlük kullanımın etkisinden kaynaklanan kavram yanılgılarının azalacağ1 düşünülmektedir (Dagher, Brickhouse, Shipman ve Letts, 2004).

Bilimin doğasını detaylı ve kapsamlı bir şekilde anlamak, evrimi destekleyen gözlem ve kanıtlar, evrim ile ilgili çalışmalarda kullanılan yöntemler, evrimin açıklayıcı ve tahmin edici gücü evrim teorisinin bilimsel statüsünün anlaşılmasında daha etkili olacaktır (American Association for the Advancement of Science [AAAS], 1993; NAS, 2008; NSTA, 2000).

Eğitimcilerin, kavram yanılgıları her ne kadar düzeltilmeye karşı çok dirençli olsa da, bu kavram yanılgılarını doğru bilimsel bilgiye çevirecek yolu bulmaları gerekiyor.

Evrim öğretiminde alternatif metotlarda kullanılabilir. Örneğin evrim konulu tek bir müze gezisinin, bilgisayar destekli simülasyon ile oluşturulan doğal seleksiyon konusu, öğrencilerin öğrenmelerini olumlu yönde etkileyebilir. Bu tip yapısalcı alternatif öğretim metotları günümüz klasik evrim öğretimine alternatif olabilirler (Weeks, 2013).

Wescott ve Cunningham (2005)'ın tavsiye ettiği üzere her öğretmenin elinin altında öğrencilerin sahip olabilecekleri kavram yanılgılarını belirleyecek bir test olmalıdır. Uygun testler kullanılarak belirlenen kavram yanılgıları öğrenciler ile paylaşılmalı ve onlara bu kavram yanılgılarının yerine doğru bilimsel bilgileri koyma fırsatı verilmelidir ki öğrencilerimizin evrimi anlama düzeyleri gelişebilsin.

Dobzhansky (1973)' in söylediği gibi “evrim teorisi biyoloji biliminin temelini oluşturur ve evrimin açıklayıcı etkisi olmadan biyolojide hiç bir şey mantıksal çerçeveye oturtulamaz" sözü düşünüldüğünde biyoloji öğretmen adaylarında görülen kavram yanılgıları daha da önemsenmesi gereken bir hal almaktadır. Eğer öğretmen adaylarımız evrim teorisini yeterince iyi anlamamış ise ileride öğretmen olduklarında evrim teorisini öğrencilerine etkili bir şekilde anlatamayacakları açıktır. Hatta öğretmen adaylarımıza bu gibi araştırma sonuçlarını göstererek onlara ilerde neler ile karşılaşabilecekleri hakkında bilgi sahibi yapmak onların ilerde kendi öğrencileri içinde daha iyi öğrenme ortamları oluşturmalarını sağlayabilir. 


\title{
Misconceptions of Prospective Biology Teachers about Theory of Evolution
}

\author{
Bülent KESKİN ${ }^{1}$, Esra ÖZAY KÖSE²
}

\author{
${ }^{1}$ Işıklar Multi-Program Anatolian High School, Akçaabat, Trabzon; ${ }^{2}$ Atatürk \\ University, Kazım Karabekir Education Faculty, Erzurum
}

Received : 20.03.2017

Accepted : 25.10 .2017

\begin{abstract}
Constituting a central and unifying base for all biological fields, theory of evolution is an interdisciplinary subject and plays an important role in understanding some basic concepts of biology. The main purpose of this study is to identify the misconceptions of prospective biology teachers about the theory of evolution. The study was conducted with 117 prospective biology teachers attending the Department of Biology in Education faculty of Atatürk University in Turkey. A two tier misconception identification test consisting of true-false questions on what the theory of evolution was used. Based on qualitative and quantitative data obtained from test, it was found that teachers carry a great deal of misconceptions about this subject. It is noteworthy that majority of the prospective biology teachers have misconceptions about the basic theory and concepts of evolution as well as concepts describing the evolutionary process. Suggestions were made to address and eliminate possible causes of these misconceptions.
\end{abstract}

Key words: misconceptions, prospective biology teachers, theory of evolution, biology education.

\section{Introduction}

Concept teaching is the most significant phenomenon that requires due consideration in learning processes. By gaining an understanding of the concepts for a particular field, relations between such concepts create a basis for new topics to be learned or taught. Therefore, wrong or incomplete teaching of a concept would trigger the subsequent relations, so this would lead to knock-on conceptual defects or misconceptions (Atasayar, 2008).

Misconceptions occurring in the minds of students prevent building of healthy ties with new concepts and significantly impair the realization of the meaningful learning process. For the effective teaching of knowledge, it is crucial to eliminate existing misconceptions and

\footnotetext{
* Corresponding Author: Bülent KESKİN, Dr., Iş1klar Multi-Program Anatolian High School, Akçaabat, Trabzon, TURKEY.

E-mail: kesbul@yahoo.com

Note: This article was produced from the first author's doctoral thesis under the supervision of second author
} 
know about misconceptions in advance in favor of avoiding new misconceptions (At1lboz, 2004).

Misconceptions outcropped in daily life emerge when students logically reason based on their emotional information with limited information. It is shown that students may be equipped, upon teaching, with various background knowledge and concepts differing from those accepted by scientific communities, and such preliminary conceptions may prevent them from truly learning scientific principles and concepts. If background information is incorrect, then further knowledge built upon them may also be incorrect (Ausubel, 1968). Ideas of students may sometimes differ from scientifically accepted values or be incomplete. It would not be wrong to conclude that, learning realized by building a link with past and new information may be incomplete (Özmen \& Demircioğlu, 2003).

Students need to understand the content of pure and applied sciences. This is the only way of interpreting their own natural world and developing essential explanations for any phenomena they encounter. Helping to eliminate the misconceptions of students is directly correlated to streamlining their process of understanding the natural world they are a part of. When students first attend the formal science classes, they carry with them intuitions, prejudices and life experiences that are usually considered inconsistent. Such a combination induces various challenges in teaching the concepts during science classes (Yağbasan \& Gülçiçek, 2003).

Studies in the field of biology reveal that teachers, prospective teachers and high school students have incomplete knowledge of and carry misconceptions about photosynthesis, ecology, plant biology, digestion, excretion, enzymes, cell division, classification, food web, osmosis-diffusion, genetic, diversity of creatures, aerobic and anaerobic respiration, vascular plants, growth and development of flowering plants, greenhouse effect, vertebrate and invertebrate species, food chain, cell and evolution (Gülev, 2008; Kete, 2006; Tekkaya, Çapa \& Y1lmaz, 2000). And among such subjects misconceived, evolution is ranked first, and it was found that teachers, prospective teachers as well as students carry myriad of misconceptions about the concept of biological evolution (Baker and Piburn, 1997; Bergman, 1979; Blackwell, Powell \& Dukes, 2003; Dagher \& BouJaoude, 2005; Author, 2010; Woods \& Sharmann, 2001).

Research of misconceptions on evolution has examined various aspects. These studies indicate that most students understand the concept of evolution as scientific theory although somewhat various degrees of understandings and misconception were presented depending on 
their grade levels, gender difference, or major areas if it comes for high school or undergraduates (Seo and Clement, 2016; Yates and Marek 2015; Yates and Marek 2014; Heady and Sinatra, 2013). According to results of these study, student may hold many misconceptions about, the nature of scientific theories, and the testability of evolution. Students' common misconceptions are the age of the universe, history of living organisms, humans' relationship to monkeys, and NOS (Borgerding et al., 2015). Apart from the listed, there are also the following expressions: 'A scientific theory that explains a natural phenomenon can be classified as a "best guess" or "hunch", students tend to agree with the misconception. Students who possess misconceptions of scientific theory typically understand theory in the speculative sense as in evolution is only a theory. Expression to a misconception, “Evolution is only a theory, and it hasn't been proven."

Evolution constitutes a connective basis for all of the foregoing fields of biology (Grace, 2011). Evolution that can be regarded as central to biology is an interdisciplinary subject and plays a key role in understanding the basic subjects of biology including the structure of cell, cell division, inheritance, reproduction and so on (Banet \& Ayuso, 2003; van Dijk, 2009; van Dijk \& Kattman, 2009). Theory of evolution forms the basis of biology, and nothing in biology makes sense except in the light of evolution (Dobzhansky, 1973). Similarly, Gould (1982) likens a biology education not supported by the theory of evolution to chemistry without periodic table. Many researchers argue that it is not possible to understand modern biology without an understanding of evolution (Bishop \& Anderson, 1990; Dobzhansky, 1973).

What is our origin? Where are we destined to? How can we live on the earth? How was our universe formed? Are among most popular questions that mankind has been pondering for ages. This refers to the mankind's ontological curiosity about its past and future. Right at this point, the theory of evolution comes into the play. Since the theory of evolution is capable of answering the majority of these mankind's questions under the guidance of scientific knowledge (Demirsoy, 1994).

Biological evolution is the root cause of the diversity of life and its common origin, and it is the natural selection that makes it true. Biological evolution occurs through natural selection that induces a change in the frequency of alleles in the gene pool. This is also a very slow process. It is obvious that there are problems in teaching the theory of evolution in Turkey. A study published in the journal Science reveals United States and Turkey as the two foremost countries where the theory of evolution is least welcomed (Miller, Scott \& Okamoto, 2006). Miller, Scott and Okamoto (2006) argue that the probable cause underlying 
the low rate of adoption of the theory of evolution by people is that people do not understand the concepts of biology in a broad sense. Understanding the theory of evolution from a scientific standpoint is very complex and multifaceted (Gould, 2002; Miller, 1999), so it is not surprising to see misconceptions in individuals failing to develop a good knowledge of theory of evolution (Miller, 1999).

Researchers attribute the difficulty experienced by teachers and students in understanding the theory of evolution to the misconceptions they carry and their information background (Gregory, 2009; Meir, Perry, Herron \& Kingsolver, 2007). People usually tend to create reasons associated with their previous knowledge and experience when they cannot understand (Moore, 2002). Moreover, this urges the individual to fill the gaps in the theory of evolution with incorrect information that prevents full understanding of the theory. Therefore, it is necessary to maintain the focus of our people in understanding the science, and avoid misconceptions to ensure that individuals who are prospective researchers of the future are not adversely influenced. Identification of misconceptions in students on evolution through this study will help to eliminate these misconceptions and build a better understanding of the scientific theory and evolution in students.

\section{Purpose}

The main purpose of this research, since it is naturally the responsibility of the biology teachers to effectively teach the theory of evolution in the class, is to identify misconceptions in prospective biology teachers about evolution.

\section{Methods}

\section{Research Model}

Research that was made to identify prospective biology teachers' misconceptions about evolution is an embedded design of mixed methods research that collects, analyzes, and mixes both quantitative and qualitative methods in a single study. The purpose of the embedded design is to collect quantitative and qualitative data simultaneously or sequentially, but to have one form of data play a supportive role to the other form of data (Creswell, 2008).

\section{Sample}

In order to identify misconceptions in what the theory of evolution is, a study sample was constructed from 117 prospective biology teachers of grade 2, 3, 4 and 5 in Department of Secondary Education for Science and Mathematics, in Kazım Karabekir Faculty of Education, Atatürk University in Turkey. 


\section{Data Gathering Tool}

Some procedures were followed during the development of Misconception identification test 1 ) Literature review, 2) creating the item pool and developing the trial form, 3) evaluating the trial form by taking the expert opinion, 4) calculation of item-total correlations for item analysis, 5) Crombach Alpha internal consistency reliability

The measuring tool employed in this study was set up through the consideration by researchers of misconceptions addressed in the literature (Köse, 2010; Fahrenwald, 1999; Gregory, 2009; Pazza, Penteado \& Kavako, 2010; Rutledge \& Warden, 1999; Understanding Evolution, 2013; Varela, 2009; Yates, 2011). Test included subthemes: what evolution, how evolution works, reconstruction, diversity, evidence, fossil, intermediate form etc. The misconception identification test consists of 14 true-false questions structured in a two-tier diagnostic test (Table 1). In a two-tier diagnostic test, the first tier addresses the reasons driving the student answers while the second tier seeks open-ended answers. The second tier of the test is structured in an open-ended layout in an aim to better measure the reasoning capacity of students and further identify whether alternative concepts differing from preidentified misconceptions exist. (Mann \& Treagust, 1998; Voska \& Heikkinen, 2000).

To ensure the scope of validity of the scale, expert opinion was previously taken. Thus, the trial form which included totally 14 items, was evaluated by two experts and 14 items were used without changing upon recommendations from experts.

The test consists of 14 questions was conducted as pilot study 43 students that studying department of biology in Erzincan University and applied to an item analysis and reliability analysis. According to item analysis; the average of item difficulty of the test is around 0.62. Substances that have difficulty landed between 0,35 to 0,64 are medium and not need to be corrected (Sözbilir, 2010). The average distinctiveness of the test was estimated at 0.39. Substances that have distinctiveness landed between 0,30 to 0,40 are well and not need to be corrected (Çalık \& Ayas 2003).

According to reliability analysis for with 43 students; Cronbach's alpha coefficient of test was found to be 0,826 . The test is a highly reliable. 
Table 1

Misconception identification test

$\begin{array}{llcl}\text { Item Items } & \text { True False }\end{array}$

\section{Number}

1 Theory of biological evolution is a theory that explains how the life began.

2 According to the theory of evolution, evolution of creatures is not fully a random or occasional process.

3 The core object of evolution is to create a chain of creatures ranging from the simpler to the more perfect.

4 Theory of evolution can neither be observed nor tested.

X accepted.

6 The theory of evolution answers questions about the diversity of life.

7 Lack of transitional forms between species in fossil records refutes the theory of evolution.

8 The theory of evolution is a theory supported by evidence. $\mathrm{X}$

9 The theory of evolution is collapsing and scientists progressively lose their faith in the theory of evolution day to day.

10 The exclusive scientific authority in the theory of evolution is not Darwin.

11 Not individuals but populations undergo evolution.

X

12 When a creature evolves into another, the older creature does not necessarily extinct.

13 Species originate from a common ancestor and transform over time.

14 Evolution is the change in the frequency of alleles making up of a population's gene pool.

\section{Data Analysis}

In identifying the misconceptions of prospective biology teachers in what the theory of evolution is, frequency and percentage distribution were used for true-false test items. Descriptive analysis as a qualitative data analysis method was employed for the part where 
reasons driving the answers were specified. Responses were read through several times to obtain a sense of the whole. Similar answers were combined and the final categorization was made and frequency were calculated for each item (Table.3). Also, data were categorized by two researchers in order to test the reliability of the obtained results.

\section{Results}

Frequency and percentage data relating to answers to the misconception identification test on what the theory of evolution is are provided in Table 2.

Table 2

Results of the first tier of the misconceptions about evolution questionnaire

\begin{tabular}{crrrrrr}
\hline \multirow{2}{*}{ Items } & \multicolumn{2}{c}{ True } & \multicolumn{2}{c}{ False } & \multicolumn{2}{c}{ Blank } \\
\cline { 2 - 7 } & f & \% & ffo & \% & f & \% \\
\hline 1 & 64 & 54.70 & 50 & 42.74 & 3 & 2.56 \\
2 & 75 & 64.10 & 39 & 33.33 & 3 & 2.56 \\
3 & 92 & 78.63 & 22 & 18.80 & 3 & 2.56 \\
4 & 45 & 38.46 & 68 & 58.12 & 4 & 3.42 \\
5 & 14 & 11.97 & 101 & 86.32 & 2 & 1.71 \\
6 & 58 & 49.57 & 56 & 47.86 & 3 & 2.56 \\
7 & 82 & 70.09 & 25 & 21.37 & 10 & 8.55 \\
8 & 31 & 26.50 & 82 & 70.09 & 4 & 3.42 \\
9 & 94 & 80.34 & 18 & 15.38 & 5 & 4.27 \\
10 & 95 & 81.20 & 13 & 11.11 & 9 & 7.69 \\
11 & 57 & 48.72 & 50 & 42.74 & 10 & 8.55 \\
12 & 75 & 64.10 & 36 & 30.77 & 6 & 5.13 \\
13 & 65 & 55.56 & 51 & 43.59 & 1 & 0.85 \\
14 & 80 & 68.38 & 21 & 17.95 & 16 & 13.68 \\
\hline $\mathrm{n}=117$ & & & & & &
\end{tabular}

Table 2 reveals that almost $80 \%$ of the prospective biology teachers picked wrong answer choices for 2 out of 14 questions (question 5 and 9). In addition, almost $70 \%$ of the teachers picked wrong answer choices for 3 out of 14 questions (question 3, 7 and 8). And almost $50 \%$ of the teachers picked wrong answer choices for 1 out of 14 questions (question 1). In other words, more than half of the prospective biology teachers picked wrong answer 
choices for 6 questions. For the remaining 8 questions, prospective biology teachers picked wrong answer choices by less than 50\%. For 1 question out of 14 , almost $81 \%$ prospective biology teachers picked the right answer choice (question 10).

Reason of true-false answers given to the misconception identification test on what the theory of evolution is has individually been read to classify misconceived statements into following categories (Table 3).

Table 3

Misconceptions about evolution

\section{Item Misconceptions}

Frequency

Evolution delivers information on the genesis of mankind.

2

Evolution delivers information about how the world has formed. 15

1

Evolution has tried to explain how the first creature occurred.

2 Fish has randomly transformed into frog and gone ashore.

The theory of evolution occurs by chance.

Evolution is a progressively advancing complex progress.

Thanks to evolution, unicellular organisms appear first followed

by the emergence of complex creatures.

3 Since life switches to land life from the marine life, the goal of the 13

theory of evolution is switch to perfection.

Human is the most perfect creature emerging through evolution. 14

Through evolution, creatures have progressed from simple to the 26

complex.

The theory of evolution can be tested in today's conditions, but has no validity.

$4 \quad$ Events in the past are unobservable and left behind.

The theory of evolution cannot be observed because it is

necessary to know about the characteristics and structure of old creatures, and this is not possible.

The theory of evolution lacks a scientific nature.

Evolution has not sufficiently been supported by evidence and has 40 not been accepted 
There is no concrete information in evolution.

The theory of evolution only responds to the diversity of animals. 5

There is no link between the theory of evolution and diversity of 20 life.

Fossil records refute the theory of evolution.

Refuting the theory of evolution is the lack of transitional forms

7 between species.

No intermediate form has been found so far.

If theory of evolution was true, then there should be fossils of all

creatures ranging from the simplest to the most complex.

8 Evolution is not a law yet, it is not accepted since it is a theory. 26

Evolution is a theory accepted based on assumptions. 27

The theory of evolution is no longer accepted today. $\quad 9$

9 With increase in the number of scientific researches, faith of 8 scientists in the theory of evolution has weakened.

Most scientists do not believe in evolution. 28

11

Evolution happens when individuals evolve, however population does not evolve.

A creature should lose all of its properties to evolve.

An evolving creature becomes extinct, otherwise number of creatures would increasingly rise leading to an imbalance.

12 Dinosaurs became extinct due to an upcoming new creature.

If a creature evolves, it hands over all of its properties to the new creature and becomes extinct.

Since the emergence of the new creature is a need-based process, 7 the need disappears and the old creature becomes extinct.

13 Each type has a specific ancestor.

There is no common ancestor between the species.

10,14

These two items are mostly empty and misleading, and there are no misconceptions.

\section{Discussion}


Since it is naturally the responsibility of the biology teacher to effectively teach the theory of evolution in the class, this study aims to identify misconceptions in prospective biology teachers about evolution. The results reveal that the teachers ticked up too many wrong answers and that they carry many misconceptions as reflected by the supporting arguments accompanying their answers.

$54.70 \%$ of the students provided wrong answers to the first question (Table 2). When students were asked about the reason, it was observed that some of them misconceived biological evolution as a theory describing how earth was created while some misconceived it as one describing how the first creature formed. In fact, biological evolution is not about the origin of life but its diversity. It focuses on how life has diversified so much rather than how it emerged (Understanding Evolution, 2013). The definition "evolution provides a logical description of multiplicity in the world of creatures" emphasizes how important education of evolution is in biology (Bozcuk, 2007). The most important factor that makes it difficult for the society to accept the theory of evolution is the fallacy that exploring evolution and the origins of life mean the same (Köksal \& Arslan, 2007). Evolution does not explore the origin of life; however the latter may be addressed only as a fictional scientific problem. As Gould (1987) argues, "evolution explores the means and mechanisms of the organic variation occurring after the onset of life." Making this distinction when teaching evolution breaks the resistance of majority of the students against understanding evolution (Clough, 1994). In summary, the theory of evolution rather focuses on how life evolves after genesis. Science attempts to clarify how life started (e.g. in a deep estuary where organic molecules accumulated, etc.), but these are not the key concepts of the theory of evolution. Not how life began but how life diverged and diversified after genesis are the focal processes addressed by evolution.

$33.33 \%$ of the students provided wrong answers to the second question (Table 2). When asked about the reasons, majority of the students are observed, as demonstrated by the statements above, to have opinion that the theory of evolution is totally aleatory. However, despite mutations cropping genetic variations are random (Hasenekoğlu, 2002), selection of individuals capable of adapting and transferring this capability to next generations is not random (Pazza, Penteado \& Kavako, 2010, Understanding Evolution, 2013). Natural selection is a process structured across a well-defined goal rather than a random one (Varela, 2009).

$78.63 \%$ of the students provided wrong answers to the third question (Table 2). When asked about the reasons, majority of the students are observed, as demonstrated by the 
statements above, to carry an image of evolution extending from the simpler towards the more complex. The opinion ends up with the judgment that human is the most perfect creature. Actually, as one of the most important mechanisms of the theory of evolution, natural selection neither selects members with strengths nor allows the transfer of such strengths to next generations, but only selects individuals capable of surviving under existing conditions (Hasenekoğlu, 2002). Natural selection is not merely a selection towards better properties. Rather it is a selection process where members with poor properties may also be selected (Understanding Evolution, 2013). One of the basic principles of Darwin's theory is that "there is no objective ground rendering a species superior to others (Dawkins, 2004). In other words, no creature needs to be perfect. In a habitat, a "better" one may not be that good in another habitat. Selection value does not depend on progression but the environment.

$38.46 \%$ of the students provided wrong answers to the fourth question (Table 2). When asked about the reasons, majority of the students are observed, as demonstrated by the above statements, to carry the misconception that variations in creatures date back to prehistoric time, therefore, since evolution took place in the past, it is impossible go back to history and observe this process. Actually, such misconception may rather be attributed to poor knowledge of students in how science works. Because many of the scientific researchers do not involve experiments or direct observations. Astronauts cannot hold the stars; geologists cannot go back to the past. Likewise, evolutionary biologists make observations in today's world and work by making comparisons. Evolutionary laboratory experiments may be carried out with creatures having a short life span (Understanding Evolution, 2013). Today, organisms getting evolved under a laboratory setting or in the natural life can be observed (Varela, 2009).

$86.32 \%$ of the students provided wrong answers to the fifth question (Table 2). When asked about the reasons, some of the students are determined, as demonstrated by the statements above, to have the misconception that there is no evidence supporting the theory of evolution. This is mainly underpinned at the arguments of anti-evolution groups, in particular in press and media, that there is no evidence of evolution. Scientific theories are broad descriptions made for a particular phenomenon. Gaining the acceptance of scientific communities owes to sufficient number of evidences from distinct fields. And the theory of evolution is sufficiently supported by evidences and accepted (Understanding Evolution, 2013). Evidences supporting the theory of evolution are abundant, diversified and originate from distinct fields (Alters \& Alters, 2001; Hasenekoğlu, 2002). 
$47.86 \%$ of the students provided wrong answers to the sixth question (Table 2). When asked about the reasons, some of the students are observed, as demonstrated by the statements above, to have the misconception that evolution does not explain diversity at all or that it explains diversity only in animals. This statement results from a misconception about the nature of science. All scientific theories are constantly flourishing. And new evidence leads to new ideas and reshapes our understanding of how earth functions. Even though we do not know everything, we strive much to figure out the unknown thanks to the contribution of science. In the future, we will keep learning tons of new information. Despite the theory of evolution does not explain everything in nature, it offers knowledge proven through thousands of experiments and observations in a wide range of fields. Now, the theory of evolution is the unique scientific theory explaining the diversity of life (Understanding Evolution, 2013).

$70.09 \%$ of the students provided wrong answers to the seventh question (Table 2). When asked about the reasons, majority of the students are observed, as demonstrated by the statements above, to have the misconception that there are no transitional fossils between species. This may be underpinned at the consistent arguments of anti-evolution groups, again in press and media, that there are no transitional forms between species. If theory of evolution is true, then there should be fossils of intermediate forms showing the cross-transition of living species in fossil records. Indeed, paleontologists have found myriad of transitional form fossils providing the link between modern species and older forms (Varela, 2009). For example, there is a serial intermediate form fossil for the size and shape of the skull showing transition from mammals to reptiles (Hasenekoğlu, 2002). It is true that there are gaps in fossil records. But this cannot serve as an evidence that may be employed against the theory of evolution. If the theory of evolution is true, then we may not necessarily expect to find the fossil records of these transitional forms. Because fossils of many creatures could not be kept up to the present time. Despite this, paleontologists have found and continue to find many fossils of organisms with transitional forms (Understanding Evolution, 2013).

$70.09 \%$ of the students provided wrong answers to the eighth question (Table 2). When asked about the reasons, majority of the students are observed, as demonstrated by the statements above, to have the misconception that this is not supported by or this is refuted by proof. In fact, the theory of evolution is the most comprehensive and powerful description that explains, by employing the evidences it has picked through distinct disciplines, the similarities and differences of creatures on earth (Alles, 2001). Science is a competitive effort, 
scientists have the enthusiasm to work, and if there are defects in the theory, then it will be the scientists who will cure them (Understanding Evolution, 2013).

$80.34 \%$ of the students provided wrong answers to the ninth question (Table 2). When asked about the reasons, some of the students are observed, as demonstrated by the statements above, to believe that theory of evolution means atheism, and some have the misconception that many scientists already reject evolution. The theory of evolution is not collapsing, scientists accept the theory of evolution, and a wide spectrum of evidences derived from distinct disciplines support that it is the best explanation about the diversity of life (Hasenekoğlu, 2002). Scientists do not argue whether evolution exists or not, but only discuss how the details of evolution have occurred (Understanding Evolution, 2013).

$11.11 \%$ of the students provided wrong answers to the tenth question (Table 2). When asked about the reasons, some of the students are observed to leave this part blank, and some stating irrelevant details, therefore no misconceived statement is found for this question.

$42.74 \%$ of the students provided wrong answers to the eleventh question (Table 2). When asked about the reasons, majority of the students providing false answers are observed, as demonstrated by the statements above, to have the misconception that individuals have undergone evolution. Students typically have the misconception that, for instance when a brown bear is taken to the poles, it would turn to white, in other words the individual would evolve. This may be attributed to the poor knowledge about the concepts of natural selection and adaptation. To explain not the individuals but populations evolve, the African swallowtail butterfly (Papilio dardanus) population may be shown as an example. All female individuals of this species live in a collective population. The colors of individuals comprising this population are very distinct from each other. This difference represents the genetic variations in the population. If the birds hunting the butterflies prefer a certain color, then the number of individuals with this color in the population would decline, culminating in reduced rates of occurrence in the population after several generations as the reproduction of such individuals in the population is relatively low. As shown, not individuals but the population has evolved (Hasenekoğlu, 2002).

$30.77 \%$ of the students provided wrong answers to the twelfth question (Table 2). When asked about the reasons, some of the students are observed, as demonstrated by the statements above, to have the misconception that old creatures become extinct as they are not needed any longer, with some wrongly believing that they become extinct having transferred their properties to the new creature, or otherwise number of creatures would increasingly rise. In fact, there is no rule that says the old creature becomes extinct as a result of the natural 
selection. If environmental conditions change, natural selection reacts to this change by making favourite the genotypes in the gene pool capable of adapting to such new environmental conditions (Hasenekoğlu, 2002).

$43.59 \%$ of the students provided wrong answers to the thirteenth question (Table 2). When asked about the reasons, majority of the students are observed, as demonstrated by the statements above, to have the misconception that species do not have a common ancestor, but each species with its own specific ancestor. This may be attributed to interpretations based on religious texts, and to the belief that each species was created independently. According to the theory of evolution, species branch out from a common ancestor (Hasenekoğlu, 2002).

$17.95 \%$ of the students provided wrong answers to the fourteenth question (Table 2). When asked about the reasons, some of the students are observed to leave this part blank, and some stating irrelevant details, therefore no misconceived statement is found for this question.

Studies in the literature on the basic theory of evolution and basic concepts support the findings of this study. Asghar's (2013) study has revealed that majority of teachers have misconceptions about the basic theory and concepts of evolution. Again, many studies in the literature reveal myriad of misconceptions about the basic theory of evolution (Asghar, Wiles \& Alters, 2007; BouJaoude et al., 2011; Deniz, Donelly, \& Y1lmaz, 2008; Fahrenwald, 1999; Graf \& Soran, 2011; Kim \& Nehm, 2010; Pazza, Penteado \& Kavako, 2010; Smith, 2010; van Dijk \& Reydon, 2010). In a study by Graf et al. (2011), propective teachers were found to have the misconception that the exclusive scientific authority in evolution is Lamarck and Darwin. Next, in his study, Weeks (2013) has observed the misconception that populations had evolved collectively. In his study, Fahrenwald (1999) found that teachers have slight misconceptions about common ancestor.

Studies in the literature have revealed that respondents accept particularly minor evolutionary variations, yet they typically have misconceptions about speciation (Southcott \& Downie, 2012). In their study, Short and Hawley (2012) have found the misconception that evolution would always create a more perfect creature, pointing to a misconception about an evolutionary chain extending from the simpler to the perfect. All these studies in the literature are consistent with the findings of this study.

Varela's (2009) study has revealed misconception in $10 \%$ of the students that lack of transitional forms between species refutes the theory of evolution. Despite many evidences and methods in Ashgar's (2013) study supporting evolution, some respondents have ignored them and argued that evolution is lack of proof. In Fahrenwald's (1999) study, 31.4\% of 
teachers do not see the theory of evolution as a scientific theory. In their study, Lord and Marino (1993) have found that almost $20 \%$ of the study population does not see theory of evolution as a scientific theory. Yates's (2011) study reveals a higher level of misconception carried by students compared to teachers that evolution is lack of supporting proof.

\section{Conclusion}

Misconceptions about adaptation and natural selection that describe the process of evolution are noteworthy (Shtulman, 2006). If students are encouraged to use the scientific language more during the class, it is believed that students would focus on the scientific content of such concepts, leading to the reduction of misconceptions resulting from the effect of daily use (Dagher, Brickhouse, Shipman \& Letts, 2004). Difficulty for students in understanding the theory of evolution results from the difficulty in understanding the concepts of genetics. Students' background knowledge in genetics would facilitate their understanding of the mechanisms of evolution, in particular the role of intra-species variation in evolution (Halden, 1989).

Some studies argue that conceptual understanding of the theory of evolution would influence the individual's acceptance of proofs about the theory of evolution (Rutledge \& Mitchell 2002; Rutledge \& Warden 2000). Above all, comprehensive understanding of the nature of science, observations and proofs supporting evolution, methods employed in studies about evolution, the explanatory and predictive power of evolution would be more influential in understanding the theory of evolution's scientific status (American Association for the Advancement of Science [AAAS], 1993; NAS, 2008; NSTA, 2000).

One of the primary reasons of the failure of correcting such misconceptions is that some pedagogic approaches pursued by teachers are not suitable for the correction of such misconceptions in students (Cunningham \& Wescott, 2009). Williams (2009) argues that, since such misconceptions occur during the early period of the individual's life, it is difficult to correct them due to social pressure, and particularly due to the fact that such concepts are remote from daily life experiences. If such misconceptions are clearly explained to students without giving the opportunity to fix them throughout the educational year, such misconceptions would exactly reinstate at the end of the year (Greene 1990; Hellden \& Solomon 2004; Mintzes et al. 2000; Wandersee et al. 1989). As suggested by Wescott and Cunningham (2005), each teacher should have a test in hand to identify the misconceptions that may be carried by students. Identifying misconceptions would also help the teacher to deliver a proper introduction in the class (Modell, Michael \& Wenderoth 2005; Wilson 2001). 
As reported by Wilson (2001), once the misconceptions of students are identified and explained, students' interest in the class grow. Certainly many teachers intend to identify the misconceptions carried by their students; however they do not have the time and competence necessary to develop a self-test for identifying the misconceptions (Morrison \& Lederman, 2000). Our teachers need reliable misconception tests with construct validity that may be employed in the education (Anderson, 2002). Misconceptions identified through appropriate tests should be revealed to the students, and they should be provided with the opportunity of substituting such misconceptions with true scientific facts so that their understanding of evolution is enhanced (Cunningham \& Wescott, 2009).

In particular, many researchers have found a positive correlation between people's opinions in science and nature of science and their level of understanding and accepting the theory of evolution (Dagher \& BouJaoude, 2005; Lombrozo et al. 2008; Rutledge \& Warden 2000; Scharmann \& Harris 1992; Trani 2004). Another finding of the study is that prospective biology teachers have misconceptions about the nature of science. prospective biology teachers argued that there is a hierarchical relationship between the theory and the law. The fact that evolution is a theory has caused doubt on prospective teachers in "evolution", and led them to, as Graf et al. (2011) argued, treat evaluation as a piece of weak scientific knowledge. Therefore, as also emphasized by many researchers (Akerson \& Volrich, 2006; Başıüyük, 2007; Dagher \& Boujaoude, 1997; Sinatra, Southerland, McConaughy \& Demastes, 2003) prior information should be presented on the definition and philosophy of science, scientific methods and process, hypothesis, theory, and the structure of the concepts of law early in teaching evolution.

To what extent propective teachers understand and accept the theory of evolution will determine how they will present the subject of evolution to their students during their subsequent teaching career (Aguillard 1999; Rutledge \& Mitchell 2002; Shankar \& Skoog 1993). Heddy and Nadelson (2012) argue that, acceptance of the theory of evolution by people would yield a global rise in the field of science and technology. Again, some other studies have revealed that, teachers rejecting the theory of evolution limit the ability of students to understand the theory of evolution (Graf et al. 2011; Rutledge \& Mitchell 2002; Sanders 2010). Moreover, it is also shown in the studies that students are greatly affected by the knowledge and world view of their teachers (Diekhoff 1983; Rutledge \& Mitchell 2002).

In conclusion, prospective biology teachers were found to have myriad of conceptions about biological evolution. The general outcome revealed is not very encouraging. Again, 
these results suggest that education on evolution is poor. Williams (2009) argues that late and limited inclusion of education on evolution in school's curriculum may underlie these misconceptions. Today, misconceptions revealed by this study and other studies in the literature are virtually identical to those revealed by Bishop and Anderson (1990). Prevalence of such misconceptions for more than 20 years despite positive enhancements in curricula, educational approaches, integration of technological innovations and other aspects of human education may be attributed to the intrinsically challenging preconceptions since the initial evolution of mankind as Geary (2007) argues. Such intrinsic formations may foster quite faster grip of socially-conveyed arguments that generally conflict with science by human mind (Coley \& Muratore, 2012).

Even though misconceptions are very resistant against correction, educators should devise ways to invert such misconceptions into true scientific knowledge (Driver, Guesne \& Tiberghien, 1985; ReaRarnirez \& Clement, 1997; Richard, 2004; Strike \& Posner, 1992). Weeks (2013) argues that we need to find teaching methods that are much more creative than those employed in the teaching of evolution today. In some studies, it is argued that offering the evolution class throughout the whole year would create the sufficient period of time necessary to identify and cure the misconceptions (Richard, 2004). Weeks (2013) argues that much more time should be allocated to correct misconceptions and deliver an in-depth teaching of the theory of evolution, requiring the service of much more experienced teachers.

Also alternative methods can be employed in teaching evolution. For example, according to the results of a study by Spiegel et al., (2012) even a single tour to a museum themed biological evolution enhances in itself the understanding of students in evolution. Another alternative method on natural selection developed by Abraham et al. (2009) through computer-aided simulation has enhanced the learning of students. Such constructive alternative teaching methods may be an alternative to today's conventional method of teaching evolution (Weeks, 2013).

The study by a group of scientists has revealed that, in case student-centered teaching methods are employed, students' misconceptions are reduced, and evolutionary concepts used by students to explain natural selection quantitatively grow (NRC, 1998; Moore et al., 2002; Özyeral, 2008).

As suggested by Wescott and Cunningham (2005), each teacher should have a test in hand to identify the misconceptions that may be carried by students. As reported by Wilson (2001), once the misconceptions of students are identified and explained, students' interest in the class grow. Certainly many teachers intend to identify the misconceptions carried by their 
students; however they do not have the time and competence necessary to develop a self-test for identifying the misconceptions. Our teachers need reliable misconception tests with construct validity that may be employed in the education. Misconceptions identified through appropriate tests should be revealed to the students, and they should be provided with the opportunity of substituting such misconceptions with true scientific facts so that their understanding of evolution is enhanced.

If students are encouraged to use the scientific language more during the class, it is believed that students would focus on the scientific content of such concepts, leading to the reduction of misconceptions resulting from the effect of daily use (Dagher, Brickhouse, Shipman \& Letts, 2004).

Given the argument of Dobzhansky (1973), "Nothing in biology makes sense except in the light of evolution", misconceptions in biology teachers require a higher level of consideration. If prospective teachers do not gain a good understanding of the theory of evolution, it is obvious that they would not be able to effectively teach it to their students in the future (Sanders 2010). And even in case the results of such researches are introduced to the prospective teachers to render them familiar with potential experiences in the future, they may build better learning settings for their own students.

\section{References}

Abraham, J. K., Meir, E., Perry, J., Herron, J. C., Maruca, S., \& Stal, D. (2009). Addressing undergraduate student misconceptions about natural selection with an interactive simulated laboratory. Evolution: Education and Outreach, 2(3),: 393-404.

Aguillard, D. (1999). Evolution education in Louisiana Public Schools: a decade following Edwards v. Aguillard. The American Biology Teacher, 61(3), 182-188.

Akerson, V. L., \& Volrich, M. L. (2006). Teaching nature of science explicitly in a first-grade internship setting. Journal of Research in Science Teaching, 43(4), 377-394.

Alles, D. (2001). Using evolution as the framework for teaching biology. The American Biology Teacher, 63(1), 20-24.

Alters B. J. \& Alters S. M. (2001). Defending evolution: A guide to the creation/ evolution controversy. Sudbury, MA: Jones and Bartlett.

American Association for the Advancement of Science (AAAS). (1993). Benchmarks for science literacy. New York: Oxford University Press. 
Anderson, D. L., Fisher, K. M., \& Norman, G. J. (2002). Development and evaluation of the conceptual inventory of natural selection. Journal of research in science teaching, 39(10), 952-978.

Asghar, A. (2013). Canadian and Pakistani Muslim teachers' perceptions of evolutionary science and evolution education. Evolution: Education and Outreach, 6(1), 1-12.

Asghar, A., Wiles, J., \& Alters, B. (2007). Discovering international perspectives on biological evolution across religions and cultures. International Journal of Diversity in Organizations, Communities, and Nations, 6, 81-88.

Atasayar, A. (2008). Kavram Öğretimi Sürecine Yönelik İçerik Geliştirme Aracının Tasarlanması Ve Kullanışlılığı [Design And Usability of A Content Development Tool for Concept Teaching Process] (Unpublished master's thesis). Hacettepe Üniversitesi, Ankara, Turkey.

Atılboz N. G. (2004). Lise 1. Sınıf Öğrencilerinin mitoz ve mayoz bölünme Konuları İle İlgili Anlama Düzeyleri ve Kavram Yanılgıları [9th Grade Students' Understanding Levels and Misconceptions about Mitosis and Meiosis]. Gazi Eğitim Fakültesi Dergisi, 24(3), 147-157.

Ausubel, D. P. (1968). Educational psychology: A cognitive view. New York: Holt, Rinehart and Winston.

Baker, D. R., \& Piburn, M. D. (1997). Constructing Science in iddle and Secondary school classroom. Needham Heights, MA: Allyn ve Bacon.

Banet, E., \& Ayuso, G.E. (2003). Teaching of biological inheritance and evolution of living beings in secondary school. International Journal of Science Education, 25(3), 373407.

Başıüyük, H. H. (2007). Lisans ve Lisansüstü Öğretiminde Evrim Eğitimi Nasıl Olmalıdır? [How evolution education should be in the undergraduate and graduate education]. Paper presented at the meeting of Biyoloji Eğitiminde Evrim Sempozyumu, İnönü Üniversitesi, Malatya, Turkey.

Bergman, J. (1979). Attitude of university students toward the teaching of creation and evolution in the schools. Origins, 6, 64-66.

Bishop, B. A., \& Anderson, C.W. (1990). Student Conceptions of Natural Selection and its role in evolution. Journal for Research in Science Teaching, 27, 415-427.

Blackwell, W. H., Powell, M. J., \& Dukes, G. H. (2003). The problem of student acceptance of evolution. Journal of BiologicalEducation, 37(2), 58-67. 
Borgerding, L. A., Klein, V. A., Ghosh, R., \& Eibel, A. (2015). Student teachers' approaches to teaching biological evolution. Journal of Science Teacher Education, 26(4), 371392.

BouJaoude, S., Asghar, A., Wiles, J.R., Jaber L., Sarieddine, D., \& Alters B. (2011). Biology professors' and teachers' positions regarding biological evolution and evolution education in a Middle Eastern society. International Journal of Science Education, 33(7), 979-1000.

Bozcuk, N. (2007, May). Neden Bilim? Neden Evrim? [Why Science? Why Evolution?]. Paper presented at the meeting of Biyoloji Eğitiminde Evrim Sempozyumu, İnönü Üniversitesi, Malatya, Turkey.

Clough, M.P. (1994). Diminish studentse resistance to biological evolution. The American Biology Teacher, 56(7), 409-415.

Coley, J.D., \& Muratore, T.M. (2012). Trees, fish, and other fictions: Folk biological thought and its implications for understanding evolutionary biology. In K. S.Rosengren, S. K. Brem, E. M. Evans, and G. M Sinatra (Eds.), EvolutionChallenges: Integrating Research and Practice in Teaching and Learning About Evolution (pp. 22-46). New York: Oxford University Press.

Creswell, J. W. (2008). Educational research: Planning, conducting, and evaluating quantitative. New Jersey, NJ: Upper Saddle River.

Cunningham, D.L., \& Wescott, D.J. (2009). Still more "fancy" and "myth" than "fact" in students' conceptions of evolution. Evolution: Education and Outreach, 2(3), 505517.

Çalık, M. \& Ayas, A. (2003). Çözeltilerde kavram başarı testi hazırlama ve uygulama [To develop and implement a concept achievement test on Solutions]. Pamukkale Üniversitesi Eğitim Fakültesi Dergisi, 2(14), 1-17.

Dagher Z.R. \& BouJaoude S. (2005), Students' perceptions of the nature of evolutionary theory. Science Education, 89, 378-391.

Dagher, Z.R., \& BouJaoude, S. (1997). Scientific views and religious beliefs of college students: the case of biological evolution. Journal of Research in Science Teaching, 34(5), 429-455.

Dagher, Z.R., Brickhouse, N.W., Shipman, H., \& Letts, W.J. (2004). How some college students represent their understandings of the nature of scientific theories. International Journal of Science Education, 26(6), 735-755. 
Dawkins, R. (2004). Gen Bencildir [The Selfish Gene] (A, Müftüoğlu, Çev.). Ankara, Turkey: Tübitak Popüler Bilim Kitaplığı.

Demirsoy, A. (1994). Kalıtım ve evrim [Inheritance and evolution]. Ankara, Turkey: Meteksan Yayınları.

Deniz, H., Donnelly, L. \& Yilmaz, I. (2008). Exploring the factors related to acceptance of evolutionary theory among Turkish preservice biology teachers: Toward a more informative conceptual ecology for biological evolution. Journal of Research in Science Teaching, 45, 420-443.

Diekhoff, G.M. (1983). Testing through relationship judgements. Journal of Educational Psychology, 75(2), 227-233.

Dillon, A. \& Zhu, E. (1997). Designing Web Based Instruction: A Human-Computer Interaction (HCI) Perspective. In: Khan (ed.) Web-Based Instruction. Englewood Cliffs. 221-225. New Jersey, NJ: Educational Technology Publications.

Dindar, H. (1995). Ortaöğretim Kurumlarında Biyoloji Öğretiminin Yapı ve Sorunları [Structure and Problems of Biology Education in Secondary Education] (Unpublished doctoral dissertation). Gazi Üniversitesi, Ankara, Turkey.

Dobzhansky, T. (1973). Nothing in biology makes sense except in the light of evolution. The American Biology Teachers, 35, 125-129.

Driver, R., Guesne, E. \& Tiberghien, A. (Eds.). (1985). Children's Ideas in Science. Philadelphia: Open University Press." Evans EM. Teaching and learning about evolution. In: Diamond $\mathrm{J}$, editor. The virus and the whale: explore evolution in creatures small and large. 2005, 25-41. Arlington, TX: NSTA Press.

Fahrenwald, C.R. (1999). Biology teachers' acceptance and understanding of evolution and the nature of science (Unpublished doctoral dissertation). University of South Dakota, SD.

Geary, D. (2007). Educating the evolved mind: conceptual foundations for an evolutionary educational psychology. Charlotte, NC: Information Age.

Gould, S.J. (1982). Darwinism and the Expansion of Evolutionary Theory. Science, 216, 380387.

Gould, S.J. (1987). Time's arrow, time's cycle: Myth and metaphor in the discovery of geological time. Cambridge, MA: Harvard University Press.

Gould, S.J. (2002). The structure of evolutionary theory. Cambridge, MA: Harvard University Press. 
Grace, J.K. (2011). Impact of a targeted lab and lab instructor intervention on student understanding of evolution in a major's general biology (Unpublished doctoral dissertation). California State University, CA.

Graf, D., \& Soran, H. (2011). Evolutionstheorie-Akzeptanz und Vermittlung im europäischen Vergleich. Einstellung und Wissen von Lehramtstudierenden zur Evolution-ein Vergleich zwischen Deutschland und der Türkei [Attitude and knowledge of lecture students on evolution - a comparison between Germany and Turkey]. In Graf, D. (Ed.), Tagungsband Einstellung und Wissen zu Evolution und Wissenschaft in Europa [Proceedings of attitude and knowledge about evolution and science in Europe]. 141161. Heidelberg, Germany: Springer.

Graf, D., Tekkaya, C., Kılıç, D.S., \& Özcan, G. (2011). Alman Ve Türk Fen Bilgisi Öğretmen Adaylarının Evrim Öğretimine ilişkin Pedagojik Alan Bilgisinin, Tutumlarının ve Pedagojik Alan Kaygılarının Araştırılması [Research on Pedagogical Area Knowledge, Attitudes and Pedagogical Area Concerns about Evolution Teaching of German and Turkish Science Teacher Teacher Candidates.]. In Kaya, Z. (Ed.), 2nd International Conference on New Trends in Education and Their Implications. 418425. Antalya, Turkey: Siyasal.

Greene, E.D. (1990). The logic of university students' misunderstanding of natural selection. Journal of Research in Science Teaching, 27(9), 875-885.

Gregory, T.R. (2009). Understanding natural selection: Essential concepts and common misconceptions. Evolution: Education and Outreach, 2, 156-175.

Gülev, D. (2008). Biyoloji Öğretmen Adaylarının Biyoloji Konularındaki Kavram Yanılgıları, Biyoloji Öğretimine Yönelik Öz yeterlik Inançları ve Tutumları [Preservice biology teachers' misconceptions, selfefficacy beliefs and attitude toward biology teaching in biology subjects] (Unpublished master's thesis). Gazi Üniversitesi, Ankara, Turkey.

Halden, O. (1989). The evolution of species: pupils perspectives and school perspectives. International Journal of Science Education, 10(5), 541-552.

Hasenekoğlu, İ. (2002). Evrim [Evolution]. Erzurum, Turkey : Atatürk Üniversitesi Kazım Karabekir Eğitim Fakültesi

Häußler, P., Bündner, W., Duit, R., Gräber, W., \& Mayer, J. (1998). Naturwissenschaftsdidaktische Forschung: Perspektiven für die Unterrichtspraxis [Scientific Research: Perspectives for teaching practice]. Kiel, Germany: IPN. 
Heady, B. C., \& Sinatra, G. M. (2013). Transforming misconceptions: Using transformative experience to promote positive affect and conceptual change in students learning about biological evolution. Science Education, 97, 723-744.

Heddy, B.C., \& Nadelson, L.S. (2012). A global perspective of the variables associated with acceptance of evolution. Evolution: Education and Outreach, 5(3), 412-418.

Helldén, G.F., \& Solomon, J. (2004). The persistence of personal and social themes in context: Long-and short-term studies of students' scientific ideas. Science Education, 88(6), 885-900.

Kete, R. (2006). 6. sınıf fen bilgisi biyoloji konularında kavram yanılgılar1 [Misconceptions about biological subjects at 6th grade science lessons]. Dokuz Eylül Üniversitesi Buca Eğitim Fakültesi Dergisi, 19, 63-70.

Kim, S.Y., \& Nehm, R.H. (2010). A cross-cultural comparison of Korean and American science teachers' views of evolution and the nature of science. International Journal of Science Education, 33(2), 197-227.

Köksal, E.A. \& Arslan, H.Ö. (2007). Evrim Eğitimde Örnek Öğretim Deseni [Case Study in Evolution Education]. Biyoloji Eğitiminde Evrim Sempozyumu, 165-184. İnönü Üniversitesi, Malatya, Turkey.

Köse, E. Ö. (2010). Biology students' and teachers' religious beliefs and attitudes towards theory of evolution. Hacettepe Üniversitesi Ĕgitim Fakültesi Dergisi, 38(38).Author (2010). Hacettepe Üniversitesi Ĕ̈itim Fakültesi Dergisi.

Lombrozo, T., Thanukos, A., \& Weisberg, M. (2008). The importance of understanding the nature of science for accepting evolution. Evolution: Education and Outreach, 1(3), 290-298.

Lord, T. \& Marino, S. (1993). How university students view the theory of evolution. Journal of College Science Teaching, 22, 353-357.

Mann, M. \& Treagust, D.F. (1998). A Pencil and Paper Instrument to Diagnose Students' Conception of Breathing, Gas Exchange and Respiration. Australian Science Teachers Journal, 44(2), 55-59.

Meir, E., Perry, J., Herron, J.C. \& Kingsolver, J. (2007). College students' misconceptions about evolutionary trees. American Biology Teacher, 69, 71-76.

Miller, J.D., Scott E.C. \& Okamoto, S. (2006). Public acceptance of evolution. Science, 313, 765-766.

Miller, KR. (1999). Finding Darwin's God: A scientist's search for common ground between God and evolution. New York, NY: Harper Collins. 
Mintzes, J.L., Wandersee, J.H. \& Novak, J.D. (2000). Assessing science understanding: A human constructivist view. 198-223. San Diego, SC: Academic Press.

Modell, H., Michael, J., \& Wenderoth, M.P. (2005). Helping the learner to learn: the role of uncovering misconceptions. The American Biology Teacher, 67(1), 20-26.

Moore, J.A. (2002). From Genesis to genetics: The case of evolution and creationism. Los Angeles, CA: University of California Press.

Moore, R., Mitchell, G., Bally, R., Inglis, M., Day, J. \& Jacops, D. (2002). Undergraduates' Understanding of Evolution: Ascriptions of agency as a Problem for student Learning. Journal of Biological Education, 36(2), 65-71.

Morrison, J.A., \& Lederman, N.G. (2000). Science teachers' diagnosis of students' perceptions. Presented at the annual meeting of the National Association for Research in Science Teaching, New Orleans, LA.

National Academy of Sciences (NAS). (2008). Science, evolution, and creationism. Access Date: 16.10.2013 Web Site URL: http://www.nap.edu/catalog.php? record_id=11876.

National Research Council (NRC). (1998). National science education standards. Washington, DC: National Academy Press.

National Science Teachers Association (NSTA). (2000). Position statement: the nature of science. Access Date: 16.10.2013 Web Site URL: http://www.nsta.org/about/positions/natureofscience.aspx.

Özmen, H. \& Demircioğlu, G. (2003). Asitler ve Bazlar Konusundaki Öğrenci Yanlış Anlamalarının Değerlendirilmesinde Kavramsal Değişim Metinlerinin Etkisi [The Effect of Enriched Teaching Material on Students' Understanding of Acids and Bases]. Ankara, Turkey: Milli Eğitim Dergisi.

Özyeral-Bakanay, Ç.D. (2008). Biyoloji Öğretmen Adaylarının Evrim Teorisine Yaklaşımları ve Bilimin Doğasına Bakış Açıları [Prospective biology teachers approaches to the theory of evolution in relation to their understandings of the nature of science] (Unpublished master's thesis). Marmara Üniversitesi, İstanbul, Turkey.

Pazza, R., Penteado, P.R. \& Kavalco, K.F. (2010). Misconceptions about evolution in Brazilian freshmen students. Evolution: Education and Outreach, 3(1), 107-113.

Rea Ramirez, M.A., \& Clement, J. (1997). Teaching for Understanding, Part 1: Concepts of Conceptual Change and Dissonance. University of Massachusetts, Amherst, USA. 
Richard, S.M. (2004). Use of concept mapping to clarify misconceptions about natural selection in an all-male high school biology classroom (Unpublished doctoral dissertation). California State University, CA.

Rutledge, M.L. \& Warden, M.A. (1999). The development and validation of the Measure of Acceptance of the Theory of Evolution instrument. School Science \& Mathematics, 99, 13-18.

Rutledge, M.L. \& Warden, M.A. (2000). Evolutionary Theory, The Nature Of Science And High School Biology Teachers: Critical Relationships, The American Biology Teacher, 62(1), 23-31.

Rutledge, M.L., \& Mitchell, M.A. (2002). High school biology teachers' knowledge structure, acceptance, and teaching of evolution. The American Biology Teacher, 64(1), 21-28.

Sanders, M. (2010). Teaching evolution in a multi-cultural society: teachers' concerns and management strategies for coping with conflict. Pinetown, South Africa: University of KwaZulu-Natal.

Scharmann, L.C., \& Harris, W.M. (1992). Teaching evolution: understanding and applying the nature of science. Journal of Research in Science Teaching, 29(4), 375-388.

Seo, H. A., \& Clément, P. (2015). Teachers' Views on Evolution: Religion Matters in South Korea. Procedia-Social and Behavioral Sciences, 167, 96-102.

Shankar, G., \& Skoog, G.D. (1993). Emphasis given evolution and creationism by Texas high school biology teachers. Science Education, 77(2), 221-233.

Short, S.D., \& Hawley, P.H. (2012). Evolutionary Attitudes and Literacy Survey (EALS): Development and Validation of a Short Form. Evolution: Education and Outreach, 5(3), 419-428.

Shtulman, A. (2006). Qualitative differences between naïve and scientific theories of evolution. Cognitive Psychology, 52, 17-194.

Sinatra, G.M., Southerland, S.A., McConaughy, F. \& Demastes, J.W. (2003). Intentions and Beliefs in Student's Understanding and Acceptance of Biological Evolution. Journal of Research in Science Teaching, 40, 510-528.

Smith, M.U. (2010). Current status of research in teaching and learning evolution: II. Pedagogical issues. Science and Education, 19, 539-571.

Southcott, R., \& Downie, J.R. (2012). Evolution and religion: attitudes of Scottish bioscience students to the teaching of evolutionary biology. Evolution: Education and Outreach, $5(2), 301-311$. 
Sözbilir, M. (2010). Madde Analizi ve Test Geliştirme [Content Analysis and Test Development]. Alınt1 Tarihi: 16.09.2013 Web Adresi: http://olcmevedegerlendirme.files.wordpress.com/2010/09/7-madde-analizi-ve-testgelistirme.pdf.

Spiegel, A.N., Evans, E.M., Frazier, B., Hazel, A., Tare, M., Gram, W., \& Diamond, J. (2012). Changing museum visitors' conceptions of evolution. Evolution: Education and Outreach, 5(1), 43-61.

Strike, K.A., \& Posner, G.J. (1992). A revisionist theory of conceptual change. Philosophy of science, cognitive psychology, and educational theory and practice, Albany, NY: SUNY Press.

Tekkaya, C., Çapa, Y. \& Yılmaz, Ö. (2000). Biyoloji öğretmen adaylarının genel biyoloji konularındaki kavram yanılgıları [Determining misconceptions conceming general biology concepts held by prospective teachers]. Hacettepe Üniversitesi Ĕ̈itim Fakültesi Dergisi,18, 37-44.

Trani, R. (2004). I won't teach evolution, it's against my religion: and now for the rest of the story. The American Biology Teacher, 66, 419-442.

Understanding Evolution (2013). A collaborative project of the University of California Museum of Paleontology and the National Center for Science Education. Access Date: 16.10.2013 Web Site URL: http://evolution.berkeley.edu/evolibrary/misconceptions_faq.php.

Van Dijk, E.M. \& Kattmann, U. (2009) Teaching evolution with historical narratives. Evolution, Education and Outreach, 2, 479-489.

Van Dijk, E.M. (2009). Teachers ${ }^{e e}$ views on understanding evolutionary theory: A PCK study in the framework of the ERTE-model. Teaching and Teacher Education, 25, 259-267.

Van Dijk, E.M., \& Reydon, T.A.C. (2010). A conceptual analysis of evolutionary theory for teacher education. Science and Education, 19, 655-677.

Varela, R.G. (2009). Evolution Misconceptions in Roman Catholic High School Students: A Comparative Study (Unpublished master's thesis). California State University, CA.

Voska, K.W., \& Heikkinen, H.W. (2000). Identification and Analysis of Student Conception Used to Solve Chemical Equilibrium Problems. Journal of Research in Science Teaching, 37(2), 160-176. 
Wandersee, J.H., Mintzes, J.J., \& Arnaudin, M.W. (1989). Biology from the learner's viewpoint: A content analysis of the research literature. School Science and Mathematics, 89(8), 654-668.

Weeks, B.E. (2013). Unweaving misconceptions: Guided learning, simulations, and misconceptions in learning principles of natural selection. (Unpublished doctoral dissertation). Capella University, Minneapolis, MN.

Wescott, D.J., \& Cunningham, D.L. (2005). Recognizing student misconceptions about science and evolution. Age, 22(92), 23-29.

Williams, J.D. (2009). Belief versus acceptance: Why do people not believe in evolution?. BioEssays, 31(11), 1255-1262.

Wilson, J.A. (2001). Psuedoscientific Beliefs among College Students. Reports of the National Center for Science Education, 21, 9-13.

Woods, C. S., \& Scharmann, L.C. (2001). High School Students' Perceptions of Evolutionary Theory. Access Date: 16.10.2013 Web Site URL: http://www.indiana.edu/ ensiweb/pap.hsev.pdf. Erişim Tarihi: 11 Nisan 2013.

Yağbasan, R., \& Gülçiçek, Ç. (2003). Fen Öğretiminde Kavram Yanılgılarının Karakteristiklerinin Tanımlanması [Describing the characteristics of misconceptions in science teaching]. Pamukkale Üniversitesi Ĕ̆itim Fakültesi Dergisi, 13, 102-120.

Yates, T. B., \& Marek, E. A. (2014). Teachers teaching misconceptions: a study of factors contributing to high school biology students' acquisition of biological evolutionrelated misconceptions. Evolution: Education and Outreach, 7(1), 7.

Yates, T. B., \& Marek, E. A. (2015). A Study Identifying Biological Evolution-Related Misconceptions Held by Prebiology High School Students. Creative Education, 6(08), 811.

Yates, T.B. (2011). Student Acquisition Of Biological Evolution-Related Misconceptions: The Role Of Public High School Introductory Biology Teachers (Unpublished doctoral dissertation). University Of Oklahoma, OK. 